\title{
Reasoning in the social sciences
}

\author{
The World Made New : Frederick \\ Soddy, Science, Politic s and \\ Environment \\ by Linda Merricks \\ Oxford University Press: 1997. Pp. 223. £60, \\ $\$ 105$

\section{A.G. Maddock}

A Nobel laureate in chemistry and a man with a very strong social conscience, Frederick Soddy (1877-1956) is a rewarding subject for a biographer. For more than a decade at the beginning of the century he was a brilliant and productive natural scientist. Then, from shortly after the First World War to the end of his life, he forsook these studies for a rather unsuccessful foray into political and economic sciences.

His researches in his earlier period, at McGill, Glasgow and Aberdeen, complemented those of his friend Ernest Rutherford. Together they established the nature of radioactivity, the atom and isotopes. At times Soddy's achievements have been underestimated, although they never were by Rutherford. His standing was probably not enhanced by an over-adulatory account by Muriel Howorth published in 1958. Nevertheless, everyone who attended secondary school since the end of the Second World War is acquainted with his results, although they may not associate them with Soddy's name.

Soddy was always interested in the use society made of discoveries in science. Unlike Rutherford, he believed that a way would be found to tap the enormous energy associated with nuclear forces. Indeed, H. G. Wells' extraordinarily prescient novel, The World Set Free, stems from from reading Soddy's book The Interpretation of the Radium (1912).

An inspiring lecturer, his written work was always presented in a popular form. His acknowledged dislike of a mathematical approach to natural science may sometimes have been responsible for his work failing to be properly appreciated.

In 1919 he was appointed as one of the Dr Lee professors of chemistry at Oxford. (The other was F. A. Lindemann.) It undoubtedly true that Soddy was a difficult and disputatious man. But he was certainly treated rather badly by Oxford. For his first five years in this post he had neither laboratory accommodation nor a budget for laboratory expenses. A technicality even excluded him from membership of the faculty board.

Linda Merricks has carried out a great deal of research into Soddy's arguments and difficulties during this period and throughout his life. As in many biographies, undue emphasis is at times placed on what may have been trivial incidents or explosive initial reactions to a disappointment. But certainly these difficul-

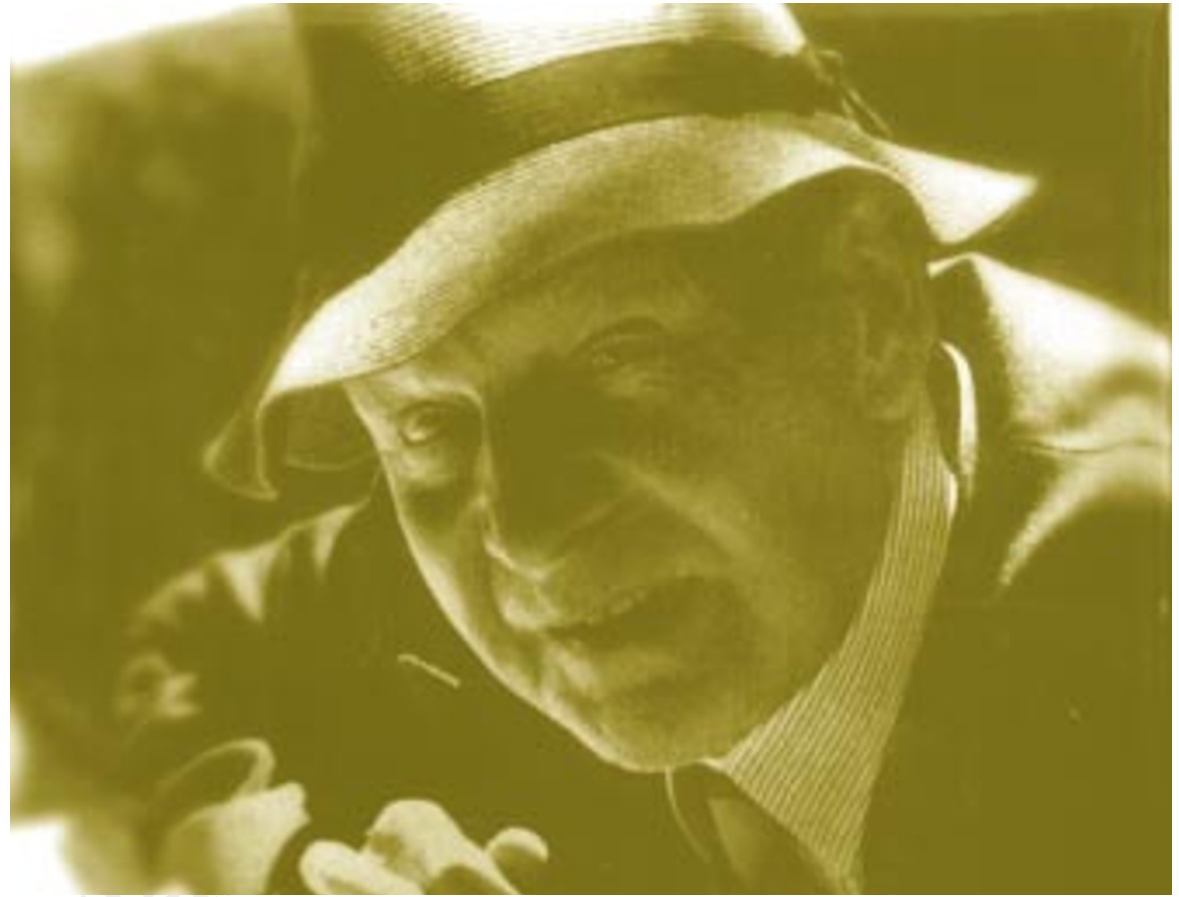

Frederick Soddy: gifted natural scientist with a mild persecution complex.

ties interrupted his research and may have led him to devote his time to the politics of the social application of science.

The author traces Soddy's involvement with various political societies and pressure groups. Soddy's ability as a lecturer led to his considerable influence on his contemporaries, but by the time J. D. Bernal was writing his classic work on the history of science he made no mention of Soddy.

Soddy's studies led quite naturally to an interest in economics, particularly the basis of money, and by 1930 he had lost practically all interest in the exact sciences. Although Merricks gives a detailed account of the people and bodies Soddy was involved with, she does not explain his ideas: indeed, she remarks that it was difficult to discover exactly what they were. So the book fails to address the question of what Soddy's activities in politics and economics achieved.

Soddy had a very happy married life, and the death of his wife in 1936 had a profound effect on him. It was followed the next year by the death of his friend Rutherford. He resigned from his Oxford chair and his life became dark and joyless until the end of the Second World War.

For several years science, politics and economics ceased to interest him and he took refuge in mathematical studies. Much of this work was confined to notebooks, but he did publish two or three papers on the fringe of mathematics. The lack of a mathematical approach in his scientific papers was a matter of choice rather than due to lack of ability.
Merricks suggests that Soddy's empirical approach to research became unsuitable after the development of quantum mechanics, but Hahn, Hevesy and Paneth and others were successful with a similar approach.

Soddy found relaxation in climbing and hill walking, developing a great liking for the Lake District. He was always fond of travel and in 1937 he revisited Ceylon, a country that had much attracted him during a voyage to Australia in 1904. The trip momentarily rekindled his interest in science and he took the opportunity to collect some monazite sand samples from Travancore.

The Second World War was inimical to all Soddy's beliefs and he played no part in it. But the dramatic ending with atomic bombs stimulated him to renewed activity, both scientific and political. His belief in nuclear power and the need for control of scientific discoveries had been vindicated. He attended scientific meetings again, and in 1949 produced the first European account of atomic power written by a scientist not involved in the wartime projects. Unfortunately, the book was poorly advertised and indeed difficult to buy, so Soddy received little credit.

The lack of appreciation of his work led to a mild persecution complex, and it is hard to escape the conclusion that such personal frustrations contributed to a large degree to a life that was, for all its early achievements, curiously unfulfilled.

A. G. Maddock is at 4 Grange Court, Pinehurst, Grange Road, Cambridge CB3 9BD, UK. 